for the all-important lond-sproading properties of the pavement. The author divides his paper into two parts. The first part consists of a review of the California bearing ratio test, and the second doals with relationships between soil dry density, compaction moisture contont and soaked/unsoaked bearing ratio. The first part is an objective survey of the California bcaring ratio test past and present. The second gives the results of considerable experimentation in terms of its title, conducted on one soil only, Heathcoto Loess; but he finds that trends in the variation of bearing ratio values with moisturo content and density should be true of a variety of soils.

\section{A Virus Disease in Crustacea}

Prof. C. VAGo, of the Laboratoire de Cytopathologie, Saint-Christol-les-Alès, has written to the Editor reporting the incidence of a virus disease in a crustacean. The virus diseases so far described in invertebrates have been either from insects or from Acaria. The prosent virus was observed in Macropipus depurator L. (Portunus depurator). Diseased animals collectod on tho French 'Languedoc' coast of the Mediterranean showed a slow dovolopment of paralysis; sometimes a slight darkening was observed at lator phases of the disease. Inoculation of blood from diseased animals into healthy ones provokod these symptoms. An infectious fraction was obtained from tho suspension of homogenized muscle, heart and gland tissue by filtering them through 450-mu 'Milliporo' membranes and by alternate centrifugation at a maximum of 30,000 r.p.m. An electron microscopic study of this fraction, after negative staining with phosphotungstic acid, revealed numerous paraspherical virus bodies, $50-60 \mathrm{~m} \mu$ in diameter (Fig. 1). The same viruses were also obtained from the tissue suspension by purification with trichlorotrifluorethane. Histological investigations of infected tissues and further analysis of the virus are in progress.

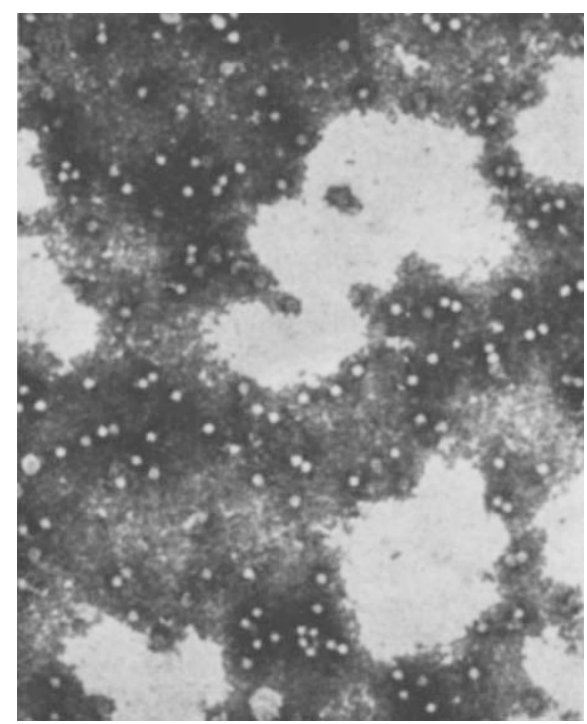

FIg. 1. Virus bodies isolated from paralysed Portunus depurator. Negative staining with phosphotungstic acid $(\times 30,000)$

\section{Hot Springs and Fumaroles at Jebel Marra, Sudan}

D. Hammerton, of the Hydrobiological Research Unit, Faculty of Scionco, University of Khartoum, has written to the Editor as follows: "The volcano of Jebel Marra (3,024 $\mathrm{m}$, latitude $24^{\circ} 16^{\prime} \mathrm{E}$., longitude $12^{\circ} 58^{\prime} \mathrm{N}$.) in Darfur Provinco, Sudan, has hitherto been regarded as extinct. It consists of a woll-doveloped caldora 3 milos in diamoter with a central cone containing a deep crater lake. A larger, shallow lake ocoupies part of the eastern floor of the caldera. Whilo ongaged on a biological investigation of the two lakes in January, 1966, I made two discoveries which suggest that the volcano must be regarded as dormant. First, a series of hot springs, ranging in temperature from $65^{\circ}-85^{\circ} \mathrm{C}$, wero found along the north-west margin of the inner crater lake. The volume of flow is probably greater than can be accounted for by precipitation and it is suggested that tho springs consist either of juvenile water or of water which leaks through the floor of the lake and is subsequently heated and forced to the su face. Secondly, oxploration of the outer north-west slopes of the inner crater revealed the prosenco of $a_{4}$ valloy in which there are numerous furnaroles emitting hot gases under pressuro. The whole valley was filled with a strong smell of sulphur dioxide, and numerous dead birds and insects were observed in the vicinity of each fumarole. Three adjacent valloys, though not $\theta \mathrm{x}$ plored in detail, appeared to contain similar fumaroles, This record of fumarolic and hot spring activity is of considerable vulcanological intorest in Africa becuuse of the northerly position of the volcano. Detailed chemical analyses have been made of the waters of the lakes and of the hot springs in conjunction with biological studies, and the results will be published elsewhere."

\section{Research Facilities at Naples, Plymouth and Windermere}

How many workers in the biological sciencos to-day aro aware of the research facilities available at the Biologica] Stations at Plymouth and Windermere and the Naples Zoological Station? The British Association for the Advancement of Science was actively concerned in the foundation of all throe of these Stations, and its continuous financial and moral support has ontitled it to table space and the use of research equipment and other material at tho Stations. The opportunity to use these facilities-in some respects unique-is open to toachers, senior students and research workers in universities, university colleges and other educational or resoarch establishments who apply to the British Association. There is no limit to the time available to applicants at the Marino Biological Station, Plymouth, and the Freshwater Biological Station, Windermere; but at tho Zoological Station, Nuples, the Association is entitled to only one month's tablo spaco during any twelve months running from July 1 to the following June 30, and for administrative reasons applications should be submitted as long in advance as possible. Successful applicants in all cases will be offered a place, free of charge, in the laboratory in question, and the use of the equipment and material necessary for carrying out tho programme of work involved. Applications should be addressed to the Secretary, British Association for the Advancement of Science, 3 Sanctuary Buildings, 20 Great Smith Street, London, S.W.1, and should include a statement of qualifications, the work in which it is desirod to engege, and the dates for which tho use of table space is required. Applications will be submitted to a committee of the Association (and in the case of the Naples Station to a Committee of the Royal Society) for approval.

\section{Scientific Research in France}

AN article in Le Progrès Scientifique (No. 91, December 1965) analyses expenditure on research and development in France in 1963. Public expenditure was 4,508 million francs, of which 110 million francs was for space research and 1,453 million frunes for military research. A further 2,073 million franes was oxpondod by private enterprise on industrial research, about 18.7 million francs by nonprofit institutions and about 82.9 million franes was pro. vided by international organizations, making a total of 6,249 million franes. Of this total, $2,267 \cdot 5$ million francs was spent in the State sector, 844.1 million francs in the educational sector, 3,103 million franes in the industrial soctor, and $34 \cdot 2$ million francs by non-profit institutions; 